\title{
Correspondence
}

\section{Gold binding to red blood cells}

Sir, We noted with interest the recent correspondence on the uptake of gold by red blood cells during treatment with sodium aurothiomalate and aurothioglucose. ${ }^{12}$ Two distinct groups have been identified, one with low concentrations of gold in red blood cells and the other with very much higher concentrations. ${ }^{1-4}$ We have also studied the distribution of gold in blood of patients with rheumatoid arthritis during treatment with sodium aurothiomalate and confirmed these results on the intersubject differences in distribution of gold. We surveyed the patients to determine factors which might affect the distribution of gold. From this survey we have identified smoking as the major factor affecting the uptake of gold by red blood cells. The ratio of the gold concentrations in red blood cells to the plasma concentrations was $0.35 \pm 0.07, n=14$ (mean \pm standard error) in smokers and $0.028 \pm 0.003, n=23$ in nonsmokers. ${ }^{5}$ The difference was highly significant $(\mathrm{p}<0.0001)$, and there was no overlap between the 2 groups.

The concentration of thiocyanate in plasma is markedly elevated by smoking. ${ }^{6}$ Preliminary studies in vitro indicate that thiocyanate significantly increases gold uptake by red blood cells. Whole blood from 5 healthy, nonsmoking volunteers was incubated with sodium aurothiomalate and varying concentrations of thiocyanate. The concentrations of gold in red blood cells after 24 hours' incubation with $0,100 \mu \mathrm{M}$, and $500 \mu \mathrm{M}$ concentrations of thiocyanate were $0.032 \pm 0.002 \mu \mathrm{g} / \mathrm{ml}$ (mean $\pm \mathrm{SE}$ ), $0.084 \pm 0.010 \mu \mathrm{g} / \mathrm{ml}$ and $0.32 \pm 0.05 \mu \mathrm{g} / \mathrm{ml}$ respectively. This may be the explanation for the increased red blood cell gold uptake in smokers.

A manuscript outlining these findings will be presented shortly.

\section{G. G. GRAHAM}

Department of Physiology and Pharmacology,

University of NSW,

Kensington, NSW 2033

G. D. CHAMPION, T. M. HAAVISTO, P. J MCNAUGHT

Departments of Rheumatology and Clinical

Pharmacology,

St Vincent's Hospital,

Darlinghurst, NSW 2010,

Australia

\section{References}

1 Gottlieb N L. Gold binding to blood cells. Ann Rheum Dis 1980; 39: 529-30.

2 Goldberg I J L, Lawton K, Redding J H, Francois P E. Gold binding to blood cells. Ann Rheum Dis 1980; 39 : 530.

3 Smith P M, Smith E M, Gottlieb N L. Gold distribution in whole blood during chrysotherapy. J Lab Clin Med $1973 ; 82$ : 930-7.
4 Van de Stadt R J, Abbo-Tilstra B. Gold binding to blood cells and serum proteins during chrysotherapy. Ann Rheum Dis 1980; 39: 31-6.

5 McNaught P J, Champion G D, Graham G G, Haavisto $T M$. The influence of smoking on the distribution of gold sodium thiomalate. Paper presented to Australian Rheumatism Association Annual Scientific Meeting, Adelaide, October, 1980. Abstract to be published in Aust NZ J Med.

${ }^{6}$ Borgers D, Junge B. Thiocyanate as an indication of tobacco smoking. Prevent Med 1979; 8: 351-7.

\section{Gout in haemoglobinopathies}

\section{Sir,}

We read with interest the paper of Rothschild et al. ${ }^{1}$ reporting 2 patients with gout associated with sickle cell disease. Their review of the previously reported cases of uric acid deposition disease in association with haemoglobinopathies unfortunately failed to include the 2 patients previously reported by us in a comprehensive review. ${ }^{2}$ Their paper makes a number of cogent points, but there are several that deserve additional comment.

(1) They suggest that the synovial fluid in patients with sickle cell anaemia and uric acid deposition disease is a transudate. There are insufficient reports of synovial fluid findings in such patients to document this. Our patient with haemoglobin SC disease ${ }^{2}$ had an exudative fluid containing leucocytes $64800 \mathrm{~mm}^{3}\left(64.8 \times 10^{9} / \mathrm{l}\right)$ (80\% neutrophils), glucose $48 \mathrm{mg} / \mathrm{dl}(2.7 \mathrm{mmol} / \mathrm{l})$, and protein $5.6 \mathrm{~g} / \mathrm{dl}(56 \mathrm{~g} / \mathrm{l})$. Clearly, more data are required to resolve this question.

(2) Both of their patients had renal dysfunction, as have all previously reported cases. ${ }^{2}$ It therefore seems likely that urate overproduction resulting from the increased red cell turnover which characterises chronic haemolytic haemoglobinopathies ${ }^{3}$ may of itself be insufficient to produce uric acid deposition disease. Relatively mild degrees of renal dysfunction, however, may predispose to its occurrence.

(3) Rothschild et al. note that the frequency of hyperuricaemia and impaired renal function in sickle cell disease is not accompanied by the expected incidence of gouty arthritis. They consider a number of possibilities for this discrepancy, including impaired leucocyte chemotaxis, reduced polymorphonuclear leucocyte activity due to anaerobic conditions, and decreased longevity of such patients. It should be emphasised, however, that the rarity of this association may well result from a failure to recognise clinical gout, the symptoms of which may be blunted by chronic analgesic use or may closely resemble those of the acute sickle crisis. Although hyperuricaemia may occur in up to $40 \%$ of adult patients, ${ }^{4}$ it is often relatively mild in degree. It is therefore essential that an 
appropriate evaluation of synovial fluid be carried out in all such patients.

Stanley P Ballou

Department of Medicine,

Case Western Reserve University.

\section{References}

1 Rothschild B M, Sienknecht C W, Kaplan S B, Spindler J S. Sickle cell disease associated with uric acid deposition disease. Ann Rheum Dis 1980; 39: 392-5.

2 Ballou S P, Khan M A, Kushner I, Harris J W. Secondary gout in hemoglobinopathies: report of two cases and review of the literature. Am J Hematol 1977; 2: 397-402.

3 Crosby W $\mathbf{H}$. The metabolism of hemoglobin and bile pigment in hemolytic disease. Am J Med 1955; 18: 112-22.

4 Gold M S, Williams J C, Spivack M, Graun J. Sickle cell anemia and hyperuricemia. JAMA 1968; 206: 1572-3.

\section{Acquired antithrombin III deficiency and systemic lupus erythematosus}

\section{Sir,}

We read with interest the report by Gladman and Urowitz on thromboembolic disease and systemic lupus erythematosus (SLE). ${ }^{1}$ The thrombotic diathesis in this group of patients was, however, not explained. It has been well established that familial antithrombin III deficiency is associated with a thrombotic diathesis. ${ }^{2}$ Kauffman and coworkers have linked an acquired antithrombin III deficiency in patients with the nephrotic syndrome to their development of renal vein thrombosis and extrarenal sites of thrombosis. ${ }^{8}$ They demonstrated a highly significant negative correlation between serum antithrombin III concentration and urinary protein excretion $(r=-0.58, p$ 2-sided $<0.001)$. Their findings suggested that the low antithrombin III levels were due to loss of the molecule in the urine. Because renal disease with proteinuria is a frequent complication of SLE, we decided to determine plasma antithrombin III levels in a group of SLE patients.

Plasma antithrombin III concentration was assayed by radial immunodiffusion (Behring Diagnostic Corp., La Jolla, CA) on 33 plasma samples from 27 patients with documented SLE, i.e., meeting at least 4 ARA criteria for SLE. ${ }^{4}$ Twenty-four hour urine collections for creatinine and protein excretion were obtained on all patients within, 1 week of the plasma sample. Creatinine clearances in all patients studied were greater than $30 \mathrm{ml} /$ minute (mean $=68 \mathrm{ml} /$ minute). Protein excretion ranged from 0 to $24.13 \mathrm{~g}$ per 24 hours (mean $=3.15 \mathrm{~g}$ per 24 hours).

There was a significant inverse correlation of antithrombin III level and urinary protein excretion $(r=$ -0.413 , p 2-sided $<0.05$ ). Antithrombin III levels were below normal in 5 patients, on at least 1 determination. Four of these patients had a rise in antithrombin III level to normal on serial determinations. In 2 of these patients there was a simultaneous dramatic decrease in urinary protein excretion of at least $6 \mathrm{~g}$ of protein per 24 hours. In the other 2 patients urinary protein excretion did not change during the period that their antithrombin III levels normalised. Both of these patients had clinical and serological evidence of active SLE at the time their antithrombin levels were low. Follow-up samples during disease remission showed normal antithrombin III levels. During the study period thromboembolic disease was not documented in any of the patients.

In conclusion, we have demonstrated that patients with SLE can have an acquired antithrombin III deficiency. There is a significant inverse correlation of antithrombin III level and urinary protein excretion. However, the normalisation of the antithrombin III levels in 2 patients occurred when their SLE became inactive, suggesting that low antithrombin III levels in SLE patients may be related to factors other than urinary protein excretion. Only a long-term prospective study of SLE patients with serial antithrombin III assays will determine if there is a relationship between and acquired antithrombin III deficiency and thromboembolic disease in SLE.

MARK P. JARRETT ARTHUR I. GRAYZEL PETER BARLAND IRA SUSSMAN

Divisions of Rheumatology (Jarrett, Grayzel, Barland) and Hematology (Sussman), Montefiore Hospital and Medical Center, Albert Einstein College of Medicine, Bronx, New York 10467, USA.

\section{References}

1 Gladman D D, Urowitz M B. Venous syndromes and pulmonary embolism in systemic lupus erythematosus. Ann Rheum Dis 1980; 39: 340-3.

2 Marcinia K E, Farley C H, DeSimone P A. Familial thrombosis due to antithrombin III deficiency. Blood 1974; 43: 219-30.

3 Kauffman R H, Veltkamp J J, Van Tilburg N H, Van Es L A. Acquired antithrombin III deficiency and thrombosis in the nephrotic syndrome. Am J Med 1978; 65: 607-13.

4 Cohen A S, Reynolds W E, Franklin E C, et al. Preliminary criteria for the classification of systemic lupus erythematosus. Bull Rheum Dis 1971; 21: 643-6.

\section{Beta-2-microglobulin in RA}

Sir, In 2 recent studies on serum beta-2-microglobulin $\left(\beta_{2} \mu\right)$ in rheumatoid arthritis $(\mathrm{RA})^{12}$ the results are somewhat divergent with regard to the correlation between $\beta_{2} \mu$ and the disease activity. We have studied the same subject and would like to report our findings.

Our material consisted of 51 consecutive inpatients with classical RA (ARA criteria 1958). One patient was excluded because of paraproteinaemia.

The clinical examination showed that the 50 patients could be separated into 2 distinct groups with regard to the disease activity. In 39 patients (mean age $53.8 \pm$ 12.0 years, range $25-72$ years) no more than a few joints were actually inflamed. Their disease was considered 